\title{
MODEL PENGELOLAAN BISNIS SYARI'AH: Studi Kasus Lembaga Pengembangan Usaha Yayasan Badan Wakaf Sultan Agung Semarang
}

\author{
Choirul Huda \\ Universitas Islam Negeri (UIN) Walisongo Semarang \\ e-mail: hudachoi99@gmail.com
}

\begin{abstract}
Islamic business management becomes an interesting topic continues to increase. There are 3 (three) models of Islamic business management: 1) Sole proprietorships, 2) Partnership, and 3) Mudharaba with cooperation between two or more parties in which the owners of capital (shahibul mal) entrust amount of capital to the manager (mudarib) with an agreement at the earliest. This paper analyze to the Islamic business management model developed by Lembaga Pengembangan Usaha (LPU) of Yayasan Badan Wakaf Sultan Agung (YBWSA) as a holding company that houses several business units. The types of business model is influence the applied business management model, and the type of business management model is influence the results of business operations. By using qualitative descriptive analysis, the study found that the LPU using multiple management models according to the type of business operation, which is a selfownership (Takessa, Air Quasa, SA Radio), and partnerships (property, retail, Pumanisa), and combination model both self-ownership and partnerships (SApress, asset management and SAtour).
\end{abstract}

Model pengelolaan bisnis syari'ah menjadi tema menarik seiring dengan perkembangannya terus meningkat. Terdapat 3 (tiga) model yang berkembang: 1) Sole proprietorships (kepemilikan tunggal), 2) Partnership (kemitraan), dan 3) Mudarabah, bentuk kerjasama dimana pemilik modal (shahibul mal) mempercayakan sejumlah modal kepada pengelola (mudarib) dengan perjanjian di awal. Paper ini menganalisa model pengelolaan bisnis syari'ah yang dikembangkan oleh Lembaga Pengembangan Usaha (LPU) pada Yayasan Badan Wakaf Sultan Agung (YBWSA) sebagai lembaga induk yang menaungi banyak unit usaha dengan prinsip syari'ah. Banyaknya unit usaha ini dapat mempengaruhi model pengelolaan bisnis yang diterapkan, dan model pengelolaan tersebut dapat mempengaruhi hasil usaha yang dijalankan. Dengan menggunakan metodfe analisis deskriptif kualitatif, penelitian ini menemukan bahwa LPU menggunakan beberapa model bisnis sesuai dengan jenis usaha yang dijalankan, yaitu kepemilikan tunggal (Takessa, Air Quasa, dan SA Radio), dan kemitraan (properti, ritel, dan Pumanisa) serta model kombinasi keduanya (SApress, manajemen aset dan SAtour).

Keywords: business management model; Islamic business; multiple management models 


\section{A. Pendahuluan}

Perkembangan bisnis Islam (syari'ah) kini kian marak dan menjamur di Indonesia. Salah satu pendorongnya adalah karena adanya kesadaran masyarakat yang mayoritas Muslim untuk menggunakan dan memanfaatkan produkproduk (barang maupun jasa) yang halāl dan țayyib. Maka peran produsen atau perusahaan-perusahaan bisnis berbasis syari'ah menjadi sebuah alternatif yang cukup menjanjikan. Perkembangan itu di satu sisi patut disyukuri, namun pada sisi lain juga perlu diwaspadai. Karena bukan tidak mungkin berbagai variasi produk syari'ah yang bermunculan saat ini ternyata tidak lebih dari sekedar 'berganti nama' saja. Artinya, secara paradigmatik sebuah perusahaan bisa saja tetap berpijak pada konsep bisnis sekuler-kapitalistik, tapi dipoles dengan labellabel syari'ah atau tepatnya label etika Islami, seperti: jujur, amanah dan sejenisnya. Hasilnya, yang penting bagi perusahaan tersebut adalah mendapatkan market share yang menguntungkan di pasar syari'ah. Inilah tantangan bagi pengusaha Muslim dalam mengembangkan bisnis yang syar'i. Bukan sekedar polesan, tapi juga asas, konsep, manusia, implementasi dan hasil yang benarbenar menampilkan karakter bisnis berbasis syari'ah yang utuh, unik dan barakah.

Terdapat beberapa prinsip bisnis dalam Islam yang tidak boleh diabaikan oleh para pelaku bisnis, baik secara pribadi maupun sebagai kelompok bisnis, yaitu: tidak boleh menggunakan cara-cara yang bathil dan merusak, ${ }^{1}$ tidak boleh melakukan kegiatan usaha dalam bentuk perjudian atau ada kemiripan dengan perjudian, ${ }^{2}$ tidak saling menzalimi dan saling merugikan, ${ }^{3}$ tidak berlaku curang dalam takaran, timbangan ataupun pemalsuan kualitas, ${ }^{4}$ dan tidak

1“Hai orang-orang yang beriman, janganlah kamu makan harta sesamamu dengan jalan yang bathil, kecuali dengan suka sama suka diantara kamu. Dan janganlah kamu membunuh dirimu, sesungguhnya Allah adalah Maha Penyayang kepada-Mu" (QS. al-Nisā [4]: 29).

2"Hai orang-orang yang beriman, sesungguhnya meminum khamar (arak), berjudi, (berkorban untuk berhala), mengundi nasib dengan anak panah, adalah perbuatan keji yang termasuk perbuatan setan, maka jauhilah perbuatan-perbuatan itu agar kamu mendapatkan keberuntungan" (QS. alMāidah [5]: 90).

3"Maka jika kamu tidak mengerjakan (meninggalkan sisa riba) maka ketahuilah, bahwa Allah dan RasulNya akan memerangimu dan jika kamu bertaubat (dari pengambilan riba), maka bagimu pokok hartamu; kamu tidak menganiaya dan tidak (pula) dianiaya” (QS. al-Baqarah [2]: 279).

4"Sucikanlah nama Tuhanmu yang Maha Tinggi, yang menciptakan, dan menyempurnakan (penciptaanNya). Dan menentukan kadar masing-masing dan memberi petunjuk “(QS. al-A'la [87]: 1-3) 
mempergunakan cara-cara yang ribawi atau dengan sistem bunga. ${ }^{5}$ Prinsipprinsip ini menjadi dasar utama dalam pengelolaan bisnis syari'ah yang dilakukan oleh pengusaha atau perusahaan. Namun dengan berbagai model bisnis yang saat ini berkembang, tidak menutup kemungkinan prinsip tersebut dilanggar sehingga berpotensi merugian pihak lain. Islam sangat melarang yang demikian itu terjadi. Dalam konteks itulah, maka model-model pengelolaan bisnis Islam menarik untuk diteliti.

Lembaga Pengembangan Usaha (LPU) sebagai salah satu lembaga di bawah naungan Yayasan Badan Wakaf Sultan Agung (YBWSA) adalah lembaga yang konsen pada pengembangan bisnis syari'ah. Banyak usaha yang saat ini sudah dikembangkan, antara lain percetakaan, tour, umrah \& haji, minimarket, air isi ulang, radio dan TV dakwah, dan lain-lain. Sebagai lembaga yang memfokuskan diri pada pengembangan bisnis syari'ah, LPU memiliki model pengelolaan bisnis dan sekaligus melahirkan ciri khas usaha tersendiri. Meskipun lokasi usahanya masih dominan di dalam kampus, yakni kampus Universitas Islam Sultan Agung (Unissula) Semarang, namun dapat berkembang dengan baik. Hal ini menarik, mengingat tradisi kampus dengan tradisi bisnis adalah dua hal yang berbeda. Kampus identik dengan teoritik, sementara bisnis lebih pada praktik. Antara teori dan praktik seringkali tidak berjalan sinergis. Namun LPU mampu mengatasinya dan bahkan mampu menumbuhkan potensi usaha yang signifikan.

Berdasarkan pada uraian tersebut di atas, studi ini bertujuan untuk mengetahui bagaimana pengelolaan bisnis syari'ah yang dikembangkan oleh LPU YBWSA Semarang dan bagaimana relasi pengelolaan bisnis syari'ah yang dilakukannya dengan perkembangan unit-unit usaha yang dikelolanya. Oleh karenanya, dengan studi ini diharapkan dapat memberikan sumbangsih bagi pengembangan ilmu ekonomi Islam, khususnya tetang pengelolaan bisnis syari'ah. Selain itu, secara praksis juga diharapkan menjadi acuan bagi para pelaku bisnis, khususnya pengusaha Muslim yang ingin mengembangkan usahanya dengan penerapan bisnis secara syari'ah.

Dengan menggunakan metode analisis deskriptif kualitatif, penelitian ini menemukan bahwa LPU menggunakan beberapa model bisnis sesuai dengan jenis usaha yang dijalankan, yaitu kepemilikan tunggal (Takessa, Air Quasa, dan

5“Allah memusnahkan riba dan menyuburkan sedekah." (QS. al-Baqarah [2]: 276). 
SA Radio), dan kemitraan (properti, ritel, dan Pumanisa) serta model kombinasi keduanya (SApress, manajemen aset dan SAtour).

\section{B. Model Pengelolaan Bisnis Syari’ah}

\section{Bisnis Syariah}

Secara umum, istilah bisnis diartikan sebagai suatu kegiatan yang dilakukan oleh manusia untuk memperoleh pendapatan atau penghasilan atau rizki dalam rangka memenuhi kebutuhan dan keinginan hidupnya dengan cara mengelola sumber daya ekonomi secara efektif dan efisien. ${ }^{6}$ Secara historis, kata bisnis berasal dari bahasa Inggris, yaitu "business", dari kata dasar "busy" yang artinya "sibuk". Sibuk mengerjakan aktivitas dan pekerjaan yang mendatangkan keuntungan. Dalam kamus bahasa Indonesia, bisnis adalah usaha dagang, usaha komersial.7 Bisnis sendiri memiliki dua pengertian yang berbeda, yakni: pertama, bisnis adalah sebuah kegiatan, dan kedua, bisnis adalah sebuah perusahaan. ${ }^{8}$

Menurut Hughes dan Kapoor, bisnis merupakan kegiatan usaha individu yang terorganisir untuk memperoleh laba atau menjual barang dan jasa guna mendapat keuntungan dan dapat memenuhi kebutuhan masyarakat. ${ }^{9}$ Ebert mengartikan bisnis sebagai sebuah organisasi yang mengelola barang dan jasa untuk mendapatkan laba.10 Dalam Islam, bisnis dapat dipahami sebagai serangkaian aktivitas bisnis dalam berbagai bentuknya yang tidak dibatasi jumlah (kuantitas) kepemilikan hartanya (barang/jasa) termasuk profitnya, namun dibatasi dalam cara perolehan dan pendayagunaan hartanya (ada aturan halal dan haram). ${ }^{11}$ Terdapat beberapa ayat di dalam al-Qur'an yang berbicara mengenai bisnis, di antaranya: al-Baqarah [2]: 282; al-Nisā' [4]: 29; al-Taubah [9]: 24; al-Nūr [24]: 37; Fāțir [35]: 29; al-Șaff [61]: 10, dan al-Jumu'ah [62]: 11.

\footnotetext{
${ }^{6}$ Muslich, Etika Bisnis Islami; Landasan Filosofis, Normatif, dan Substansi Implementatif (Yogyakarta: Ekonisia Fakultas Ekonomin UII, 2004), h. 46. 208.

${ }^{7}$ Tim Redaksi Kamus Bahasa Indonesia, Kamus Bahasa Indonesia (Jakarta: Pusat Bahasa, 2008), h.

${ }^{8}$ Husein Umar, Businnes An introduction (Jakarta: Gramedia Pustaka Utama, 2000), h. 3.

${ }^{9}$ Muhammad dan Lukman Fauroni, Visi al-Qur'an tentang Etika dan Bisnis (Jakarta: Salemba Diniyah 2002), h. 60.

10Sentot Imam Wahjono, Bisnis Modern (Yogyakarta: Graha Ilmu, 2010), h. 4.

11Ibid., h. 18.
} 
Al-Qur'an menjelaskan tentang konsep bisnis dengan beberapa kata yang diantaranya adalah kata: al-tijārah (berdagang, berniaga), al-bayi'u (menjual), dan tadāyantum (muamalah). ${ }^{12}$ Kata tijārah dalam al-Qur'an dapat ditemui dalam Surat al-Baqarah [2]: 282, al-Nisa [4]: 29, al-Taubah [9]: 24, al-Nūr [24]: 37, Fāțir [35]: 29, al-Ṣaff [61]: 10, dan al-Jumu'ah [62]: 11. Al-ba'í adalah lawan kata dari al-shira' (beli). Al-ba'i secara etimologi berarti menjual. ${ }^{13}$ Kata al-bay' disebutkan dalam Surat al-Baqarah [2]: 254, 275. Sementara kata tadāyantum disebut satu kali dalam Surat al-Baqarah [2]: 282. Al-Qur'an juga seringkali menyebut bisnis dengan menggunakan kata-kata jual-beli, untung-rugi dan lainnya sebagaimana dalam Surat al-Taubah [9]: 111.

Bisnis dalam al-Qur'an baik yang terambil dari terma tijārah, al-bay', ishtarā, maupun tadāyantum, tidak hanya menjelaskan bisnis dalam sifat material, tetapi juga immaterial. Wirausaha Muslim sebagai pelaku bisnis harus bekerja sesuai profesionalitas dan tetap menjalankan perintah Allah. Dalam konteks inilah alQur'an menawarkan keuntungan dengan suatu bursa yang tidak pernah mengenal kerugian, yaitu tijārah lan tabūrō. ${ }^{14}$ Karena bisnis berbasis syari'ah adalah kegiatan bisnis yang dilakukan oleh seseorang dengan berlandaskan syariat agama Islam, dimana setiap cara memperoleh dan menggunakan harta yang mereka dapatkan harus sesuai dengan aturan agama Islam (halal dan haram). Dalam bisnis Islam seseorang harus selalu mengingat dan menyerahkan semua hasil usaha yang telah dilakukan kepada Allah. Dengan berserah diri kepada Allah dan menganggap kerja sebagai ibadah seseorang akan selalu ikhlas dalam bekerja inilah yang dimaksud dengan tawhìd ulūhiyyah. ${ }^{15}$

\section{Prinsip Dasar dan Orientasi Bisnis dalam Islam}

Terdapat empat prinsip (aksioma) dalam ilmu ekonomi Islam yang mesti diterapkan dalam bisnis syari'ah, yaitu: tauhid (unity/kesatuan), keseimbangan

\footnotetext{
${ }^{12}$ Akhmad Nur Zaroni, "Bisnis dalam Perspektif Islam: Telaah Aspek Keagamaan dalam Kehidupan Ekonomi”, Mazahib Vol. IV, No. 2, Desember 2007, h. 177-179.

${ }^{13}$ Abdul Rahman Ghazaly, Fiqih Muamalah (Jakarta: Kencana Prenada Media Group, 2010), h. 67.

${ }^{14}$ Akhmad Nur Zaroni, “Bisnis dalam Perspektif Islam...," h. 179.

${ }^{15}$ Tawhìd ulūhiyyah adalah mengesakan Allah dalam beribadah dengan tujuan agar manusia tahu hanya kepada Allah seluruh manusia harus menyembah.
} 
atau kesejajaran (equilibrium), kehendak bebas (free will), dan tanggung jawab (responsibility). ${ }^{16}$ Tauhid mengantarkan manusia pada pengakuan terhadap keesaan Allah selaku Tuhan semesta alam. Oleh sebab itu, segala aktifitas khususnya dalam muamalah dan bisnis- hendaklah mengikuti aturan Allah. ${ }^{17}$ Sedangkan keseimbangan, keadilan atau kesejajaran (equilibrium) merupakan konsep yang menunjukkan adanya keadilan sosial. Ajaran Islam berorientasi pada terciptanya karakter manusia yang memiliki sikap dan perilaku yang seimbang dan adil dalam konteks hubungan antara manusia dengan diri sendiri, dengan orang lain (masyarakat) dan juga dengan lingkungan. ${ }^{18}$ Sementara dengan kehendak bebas, manusia mempunyai suatu potensi dalam menentukan pilihan-pilihan yang beragam, karena kebebasan manusia tidak dibatasi. Namun kehendak bebas itu harus sejalan dengan kemaslahatan kepentingan individu, terlebih lagi pada kepentingan umat. Tanggung jawab (responsibility), ini terkait erat dengan tanggung jawab manusia atas segala aktivitas yang dilakukan kepada Tuhan dan juga tanggung jawab kepada manusia sebagai masyarakat. Kebebasan dalam melakukan bisnis oleh manusia tidak lepas dari pertanggungjawaban yang harus diberikan atas aktivitas yang dilakukan sesuai dengan apa yang ada dalam al-Qur'an bahwa setiap individu bertanggungjawab atas segala aktivitasnya. ${ }^{19}$

Selain 4 (empat) aksioma yang telah disebutkan di atas, Beekun menambahkan yang kelima, yaitu benovelence atau dikenal dengan Ihsan, ${ }^{20}$ yaitu kehendak untuk melakukan kebaikan hati dan meletakkan bisnis pada tujuan berbuat kebaikan. Sedangkan orientasi bisnis dalam Islam adalah untuk mencapai empat hal utama, yaitu target hasil berupa profit materi dan benefit-non materi, pertumbuhan, keberlangsungan, dan keberkahan. ${ }^{21}$ Target hasil profit-

\footnotetext{
16Syed Nawab Haider Naqvi, Islam, Economics and Society (London and New York: Kegan Paul International, 1994), h. 44-45.

${ }^{17}$ Syed Nawab Naqvi, Ethict and Economics: An Islamic Syntesis, terj. Husin Anis, Etika dan Ilmu Ekonomi Suatu Sintesis Islami (Bandung: Mizan, 1993), h. 50-51.

${ }^{18}$ Muslich, Etika Bisnis Islami: Landasan Filosofis, Normatif, dan Substansi Implementatif (Yogyakarta: Ekonisia Fakultas Ekonomin UII, 2004), h. 37. 38).

19“Tiap-tiap diri bertanggung jawab atas apa yang telah diperbuatnya." (QS. al-Muddaththir [74]:

${ }^{20}$ Rafik Isa Beekun, Islamic Business Ethict (Virginia: International Institute of Islamic Thought, 1997), h. 54.

${ }^{21}$ Muhammad Ismail Yusanto dan Muhammad Karebet Widjajakusuma, Menggagas Bisnis Islami, (Jakarta: Gema Insani Press, 2002), h. 18.
} 
materi dan benefit-non materi artinya bahwa bisnis tidak hanya untuk mencari profit (qimah madiyah atau nilai materi), tetapi juga memperoleh dan memberikan benefit (keuntungan atau manfaat) non materi kepada internal organisasi perusahaan dan eksternal (lingkungan), seperti terciptanya suasana persaudaraan, kepedulian sosial dan sebagainya. ${ }^{22}$

Selain memperoleh profit dan benefit, bisnis dalam Islam juga memiliki orientasi pertumbuhan, keberlangsungan, dan keberkahan. Artinya, bahwa perusahaan harus berupaya menjaga pertumbuhan agar selalu meningkat, dengan tetap berada dalam koridor syari'ah, bukan menghalalkan segala cara. Apa yang sudah dicapainya tersebut harus terus dipertahankan keberlangsungannya, sehingga perusahaan dapat exis dalam kurun waktu yang lama. Pada akhirnya, apa yang sudah dicapainya tersebut juga harus memunculkan keberkahan. Artinya, bisnis syari'ah menempatkan berkah sebagai tujuan inti, karena ia merupakan bentuk dari diterimanya segala aktivitas manusia. ${ }^{23}$

\section{Model Pengelolaan Bisnis dalam Islam}

Persaingan bisnis saat ini semakin ketat. Agar organisasi dapat terus bertahan dalam menjalankan bisnis, maka harus melakukan perbaikan dan inovasi terus menerus. Menurut Giesen, Berman, Bell dan Blitz, sebagaimana dikutip oleh Melina mengatakan bahwa "anticipating massive change across diverse industries, top-performing CEOs are focusing on business model innovation as a path to competitive power and growth". ${ }^{24}$ Ini menunjukkan betapa pentingnya inovasi model bisnis dalam kekuatan kompetitif dan pertumbuhan perusahaan. Suatu model bisnis menggambarkan pemikiran tentang bagaimana sebuah organisasi menciptakan, memberikan, dan menangkap nilai-nilai, ${ }^{25}$ baik itu ekonomi, sosial, ataupun bentuk-bentuk nilai lainnya. Maka istilah model bisnis dipakai untuk ruang lingkup yang luas dalam konteks formal dan informal untuk menunjukkan aspek inti suatu bisnis, termasuk mencakup maksud dan tujuan, apa yang

\footnotetext{
22Ibid., h. 19.

23Ibid., h. 20.

${ }^{24}$ Melina Setijawibawa, "Evaluasi Model Bisnis pada Perusahaan X Menggunakan Business Model Canvas", Jurnal AGORA, Vol. 3, No. 1, 2015.

${ }^{25} \mathrm{~A}$. Osterwalder, Yves Pigneur, Alan Smith, and 470 practitioners from 45 countries, Business Model Generation, self published, 2009.
} 
ditawarkan, strategi, infrastruktur, struktur organisasi, praktik-praktik niaga, serta kebijakan-kebijakan dan proses-proses operasional.

Pada umumnya, definisi model bisnis memasukkan penciptaan nilai pelanggan sebagai salah satu elemen inti. Penciptaan nilai pelanggan yang dibahas disebutkan dalam berbagai istilah seperti "desain penciptaan nilai" atau "menciptakan nilai", tetapi makna utama dari istilah-istilah itu sama. Model bisnis harus menjelaskan bagaimana perusahaan menciptakan nilai bagi pelanggannya.. Rasulullah adalah pelaku bisnis yang sangat berhasil di zamannya. Ada dua prinsip utama yang patut dicontoh dari perjalanan bisnis Rasululah. Pertama, uang bukanlah modal utama dalam berbisnis, dan kedua, modal utama dalam usaha adalah membangun kepercayaan dan dapat dipercaya (al-amin). ${ }^{26}$ Bisnis dalam Islam merupakan segala macam kegiatan bisnis yang tidak terbatas (dalam hal kuantitas) kepemilikan barang atau jasa termasuk keuntungan, tetapi dapat terbatas dalam hal cara mendapatkan dan cara penggunaan (sesuai dengan hukum syari'ah Islam). ${ }^{27}$ Bisnis Islam yang dikendalikan oleh hukum syari'ah cukup jauh berbeda dengan bisnis konvensional, dalam hal cara untuk mendapatkan kekayaan dan bagaimana menggunakannya.

Bisnis Islam yang sesuai syar'i bertujuan untuk mencapai falāh sebagai tujuan hidup setiap Muslim. Maka dalam pengelolaan bisnis syari'ah tidak hanya memandang aspek material, namun lebih ditekankan pada aspek spiritual. Dalam konteks duniawi, falāḥ merupakan konsep yang multidimensi dan memiliki implikasi pada aspek perilaku individual atau mikro dan perilaku kolektif atau makro. ${ }^{28}$ Adapun untuk mencapai falạh tersebut dikenal konsep mașlahah. Maslahah adalah segala bentuk keadaan, baik material maupun nonmaterial, yang mampu meningkatkan kedudukan manusia sebagai makhluk yang paling mulia. Menurut al-Shatibi, mașlaḥah adalah dasar kehidupan manusia dan terdiri atas 5 (lima) hal, yaitu agama (din), jiwa (nafs), intelektual ('aql), keluarga dan keturunan (nasl) dan harta (mā $l) .{ }^{29}$

\footnotetext{
26Syafii Muhammad Antonio, Muhammad saw-The Super Leader Super Manager (Jakarta: Prophetic Leadership and Management Centre, 2007, h. 96.

${ }^{27}$ Irawan Febianto, Shariah Compliant Model of Business Entities (Bandung: Faculty of Economic University of Padjadjaran, 2010).

${ }^{28}$ Pusat Pengkajian dan Pengembangan Ekonomi Islam (P3EI) Universitas Islam Indonesia (UII) Yogyakarta, Ekonomi Islam (Jakarta: Raja Grafindo, 2013).

${ }^{29}$ Pusat Pengkajian dan Pengembangan Ekonomi Islam (P3EI) Universitas Islam Indonesia (UII) Yogyakarta, Ekonomi Islam (Jakarta: Raja Grafindo, 2013).
} 
Model bisnis pada entitas bisnis Islam bersumber dari prinsip-prinsip dan asas ekonomi bisnis Islam sebagai sumber rujukannya. Dari proses dan pengalaman dalam pengembangan ekonomi bisnis, melahirkan kristalisasi sistem nilai yang menggerakkan perilaku bisnis kolektif dalam naungan organ entitas bisnis Islam. Paduan antara ajaran agama sebagai sumber rujukan, kristalisasi perilaku bisnis dan tempaan dunia bisnis, melahirkan suatu model bisnis yang kemudian disebut model bisnis Islam.

Menurut Muhammad Akram Khan, terdapat tiga model penting dalam organisasi bisnis menurut ekonomi Islam, ${ }^{30}$ yaitu:

a. Sole Proprietorship (Kepemilikan Tunggal). Sole Proprietorship merupakan suatu usaha yang dijalankan sendiri oleh perorangan tanpa menggunakan bentuk usaha yang terpisah dan tersendiri. Sole proprietorships adalah bentuk paling sederhana dari organisasi usaha. Semua hak yang dimiliki usaha tersebut merupakan hak yang dimiliki oleh si pemilik. Demikian pula, semua kewajiban atau hutang yang ditanggung oleh usaha tersebut secara hukum merupakan kewajiban atau hutang dari si pemilik. Aset dan laba yang dihasilkan oleh usaha dimiliki oleh si pemilik yang secara pribadi berkewajiban membayar pajak apapun yang harus dibayar berkenaan dengan aset dan laba tersebut.

b. Partnership. Merupakan suatu usaha yang dikembangkan secara bersamasama oleh dua orang atau lebih untuk mendistribusikan keuntungan dari hasil usaha yang dijalankan oleh mereka. Implikasi dari definisi tersebut adalah bahwa pihak yang menjalankan partnership sama-sama mengeluarkan sumber daya yang dimiliki masing-masing. Bagi hasil menjadi tujuan utama bentuk usaha ini. Keuntungan akan didistribusikan pada proporsi yang sesuai dengan kesepakatan kedua belah pihak. Selain itu kerugian juga akan ditanggung oleh semua pihak. Pada prinsipnya Islam menghendaki keadilan dan kejujuran dalam bertransaksi. Tidak ada aturan baku yang menentukan dalam sistem bagi hasil apakah 50:50, 60:40, 70:30 dan seterusnya. Prinsipnya yang bekerja paling gigih harus menerima lebih banyak dari yang tidak berbuat.

\footnotetext{
30Muhammad Akram Khan, Types of Business Organisation in an Islamic Economy, An introduction to Islamic Economics \& Finance (Kuala Lumpur: CERT Publication SDN, BHD., 2008).
} 
S. Muḍarabah. Merupakan suatu usaha dalam bentuk kerjasama antara dua atau lebih pihak dimana pemilik modal (șāhib al-māl) mempercayakan sejumlah modal kepada pengelola (mudarib) dengan suatu perjanjian di awal. Bentuk ini menegaskan kerjasama dengan kontribusi seratus persen modal dari pemilik modal dan keahlian dari pengelola. Transaksi jenis ini tidak mewajibkan adanya wakil dari șāhib al-māl dalam manajemen proyek. Sebagai orang kepercayaan, mudarib harus bertindak hati-hati dan bertanggung jawab atas kerugian yang terjadi akibat kelalaian dan tujuan penggunaan modal untuk usaha halal. Sedangkan, șāhib al-māl diharapkan untuk mengelola modal dengan cara tertentu untuk menciptakan laba yang optimal.

\section{Jenis Usaha dan Model Pengelolaan Bisnis LPU YBWSA Semarang}

Lembaga Pengembangan Usaha (LPU) Yayasan Badan Wakaf Sultan Agung (YBWSA) merupakan lembaga yang mengembangkan berbagai jenis usaha yang teknis operasionalnya dikelola oleh dua perusahaan di bawah naungannya, yakni PT. Bhakti Agung Pratama (PT. BAP) dan PT. Radio Suara Kalimasadha Sakti (SARadio). ${ }^{31}$ PT. BAP adalah sebuah perusahaan yang mengambil bentuk usaha sebagai perusahaan holding (holding company) dan didirikan untuk mengelola berbagai jenis usaha yang sifatnya umum. ${ }^{32}$ Sebagai sebuah perusahaan di bawah payung LPU, PT. BAP mengemban amanah YBWSA untuk mengusung bisnis yang berlandaskan pada ajaran syari'ah Islam, dimana dalam pengelolaan bisnis, LPU mengutamakan kaidah manajemen professional dengan landasan prinsip syari'ah. Beberapa unit usaha yang ada di bawah koordinasi PT. BAP adalah: Percetakan Sultan Agung Press (SApress), Property, Pumanisa (Pujasera Mahasiswa dan Apresiasi Seni Sultan Agung), Depo air minum RO dan isi ulang "Quasa", Takessa (Tabung Kesehatan Sultan Agung), Minimarket Batama, Grosir Senkusa (Sentra Kulakan Sultan Agung), Aset manajemen, dan Sultan Agung Tour (SAtour). Sementara SA Radio adalah perusahaan yang bergerak di bidang jasa kepenyiaran dakwah Islam yang bercorak moderat dengan slogan "Radionya

31Profil LPU YBWSA, SA Press, 2003, h. 4.

32Tim BAP, Profile PT. BAP - LPU YBWSA Semarang (Semarang: SApress, 2010), h. 12. 
Keluarga Muslim."33 Jika PT. BAP mengelola berbagai jenis usaha, maka SA Radio khusus bergerak di bidang kepenyiaran dakwah Islam yang mengudara di jalur analog (1062 AM) dan streaming. ${ }^{34}$

Model pengelolaan bisnis yang dijalankan oleh LPU didasarkan pada beberapa unsur yang saling terkait, yaitu: dasar pijakan bisnis yang digunakan, orientasi terhadap bisnis yang dijalankan, dan model operasional bisnis syari'ah yang diterapkan.

\section{Dasar Pijakan Bisnis yang Digunakan}

Posisi LPU sebagai badan pelaksana di bawah YBWSA cukup kuat di dalam menggarap bidang bisnis yang berkaitan dengan pendidikan dan kesehatan. Hal ini dikarenakan institusi bisnis di bawah holding LPU tidak sekedar menjalankan bisnis untuk mendulang keuntungan, tetapi juga melakukan edukasi terutama kepada internal YBWSA, seperti mahasiswa Unissula, untuk belajar praktik bisnis yang didasari nilai-nilai Islam. Dalam bidang kesehatan, LPU mendirikan Takessa yang berkaitan erat dengan jaminan kesehatan karyawan YBWSA yang sangat berkaitan dengan salah satu core bidang garapan YBWSA, yaitu bidang kesehatan.

Terkait dengan hal ini terdapat empat prinsip yang menjadi pilar LPU dalam menjalankan sebuah bisnis, yaitu: prinsip keimanan, prinsip amanah, prinsip keseimbangan, dan prinsip ihsan. ${ }^{35}$ Prinsip keimanan diimplementasikan dengan menjaga shalat 5 waktu dengan berjamaah, kajian rutin mingguan, do'a pagi dan do'a sore. Prinsip ini menjadi dasar bagi LPU dalam meraih keberkahan dalam berbisnis. Prinsip amanah diimplementasikan dengan bekerja secara maksimal, profesional, dan jujur. Maka LPU secara rutin melakukan pelatihan/pembinaan yang berkesinambungan, baik pelatihan yang bertujuan untuk meningkatkan keahlian dalam berbisnis/bekerja maupun pelatihan yang bertujuan untuk meningkatkan ruhiyah karyawan agar bisa lebih menjaga amanah yang dibebankan. Prinsip keseimbangan diimplementasikan dengan

\footnotetext{
33 Profil PT. Radio Suara Kalimasadha Sakti Semarang, Semarang: SA Press, 2008.

34 Wawancara dengan Ibu Roudhotul Badiah, S.Psi, selaku Manajer Program dan Siaran PT. SA Radio, tanggal 25 Maret 2016.

35 Wawancara dengan Dr. H. Ahmad Didik Supadie, MM, sekretaris umum YBWSA pada tanggal 4 Maret 2016.
} 
pemberian reward and punishment (upah dan sanksi) yang seimbang dan pemberian penghargaan/apresiasi bagi pihak yang berprestasi. Prinsip ihsan diimplementasikan dengan mendorong pihak-pihak yang terlibat dalam bisnis LPU untuk memberikan yang terbaik bagi perusahaan.

\section{Orientasi terhadap Bisnis yang Dijalankan}

Pada beberapa kasus yang terjadi, LPU sangat menekankan pentingnya pelayanan yang maksimal dengan mengedepankan kualitas, dibanding dengan perolehan profit yang maksimal tetapi berdampak buruk pada keberlangsungan bisnis yang dikelola. Terdapat dua konsep yang saling berkaitan yang menjadi orientasi bisnis LPU, yaitu: ${ }^{36}$

a. Konsep Maslahah, yaitu bagaimana bisnis yang dikembangkan tidak hanya berorientasi mencari keuntungan (profit oreinted), tetapi juga ada manfaat lain yang hendak dicapai (benefit oreinted). Melalui konsep maslahah inilah perusahaan berupaya menjaga pertumbuhan agar selalu meningkat. Hal itu diterapkan dengan adanya unit usaha Takessa (Tabung Kesehatan Sultan Agung) dan SA Radio yang lebih pada pencapaian benefit dari pada profit.

b. Konsep Keberkahan, yaitu sebagai tujuan tertinggi yang hendak diraih. Maka cara-cara bisnis yang diterapkan harus sesuai dengan ajaran Islam dan tidak melanggar larangan-larangan dalam Islam. LPU berusaha secara maksimal mengawal setiap kegiatannya agar tidak bertentangan dengan hukum-hukum syariat Islam.

\section{Model Operasional Bisnis Syariah yang Diterapkan}

Terdapat beberapa model pengelolaan bisnis yang dijalankan oleh LPU YBWSA. Akan tetapi karena LPU YBWSA hanya sebagai koordinator saja, maka model bisnis yang dianalisa adalah model bisnis yang dikembangkan oleh dua perusahaan di bawah naungan LPU YBWSA, yaitu PT. Bhakti Agung Pratama (PT. BAP) berikut unit usaha di bawahnya dan PT. Radio Suara Kalimasadha Sakti (SA Radio). Selengkapnya diuraikan sebagaimana berikut ini:

${ }^{36}$ Wawancara dengan Drs. H. Tjuk Subchan Sulchan, wakil ketua umum YBWSA sekaligus Ketua LPU YBWSA pada tanggal 4 Maret 2016. 


\section{a. PT. Bhakti Agung Pratama (PT. BAP)}

Pengelolaan bisnis yang dilakukan PT. BAP pada dasarnya tidak jauh berbeda dengan pengelolaan bisnis pada umumnya. Namun dalam operasionalnya ada beberapa hal yang ditekankan sebagai dasar pijakan dalam pengelolaan bisnis, yaitu yang berkaitan dengan dasar bisnis yang digunakan dan orientasi bisnis sebagaimana yang sudah dijelaskan di awal. ${ }^{37}$

Menganalisa model bisnis PT. BAP harus lebih dahulu mengetahui model bisnis yang diterapkan oleh masing-masing unit usaha yang ada di bawahnya. Unit usaha yang ada di bawah payung PT. BAP menerapkan model pengelolaan bisnis yang berbeda-beda. Hal itu dapat dijelaskan sebagai berikut:

\section{b. Percetakan Sultan Agung Press (SApress)}

Perusahaan yang bergerak di bidang jasa layanan cetak ini menjalankan usahanya dengan model kombinasi antara model pengelolaan secara mandiri dengan model pengelolaan kerjasama. Secara mandiri artinya beberapa produk cetakan yang mampu ditangani sendiri oleh SApress maka ditangani sendiri. Sementara produk yang belum mampu ditangani sendiri dikerjasamakan dengan pihak lain. Hanya saja pelibatan pihak ketiga tersebut tidak menggunakan akad kerjasama bagi hasil, melainkan lebih pada konsep pengalihan order cetak dengan kompensasi pembayaran berupa sejumlah uang yang disepakati di awal. ${ }^{38}$

\section{c. Property}

Usaha properti yang dijalankan oleh PT. BAP adalah proyek perumahan yang ada di dua lokasi, yaitu Perumahan Griya Agung yang berlokasi di Bangetayu Semarang dan Perumahan Villa Agung Regency di Pudak Payung Kota Semarang dan Ungaran Kabupaten Semarang. Pada bisnis ini PT. BAP bermitra dengan beberapa pihak, diantaranya adalah dengan pemilik tanah dan kontraktor (pihak yang menangani pembangunan unit rumah). Konsep kemitraan dengan pemilik tanah adalah dengan cara pembelian lahan tanah

37Wawancara dengan Heri Poerbantoro selaku Direktur Utama PT. BAP, tanggal 20 Maret 2016.

38Wawancara dengan Wahyu, Manajer Sultan Agung Press, pada tanggal 20 Maret 2016. 
melalui pembayaran tempo saat tanah dan rumah laku terjual. Pola kemitraan ini sangat membantu PT. BAP dalam permodalan. PT. BAP tidak perlu menyediakan dana khusus (modal awal) untuk pembelihan lahan tanah, karena sudah disediakan oleh pihak mitra. Bahkan pembayarannya bisa berlaku tempo saat tanah dan rumah tersebut sudah laku. Selain itu masih ada distribusi bagi hasil dari nilai total profit usaha property ini saat semua lahan tanah dan bangunan habis terjual. ${ }^{39}$

\section{d. Pumanisa (Pujasera Mahasiswa dan Apresiasi Seni Sultan Agung)}

Pumanisa berada di sebuah gedung milik YBWSA yang terdiri atas tiga lantai. Lantai 1 adalah untuk layanan jasa mahasiswa yang bersifat umum (non makanan), lantai 2 dipergunakan untuk layanan jasa makanan dan minuman (pujasera), sedangkan lantai 3 dimanfaatkan untuk ruang kuliah mahasiswa keperawatan Unissula. Model pengelolaan usaha pada lantai 1 dan 2 tidaklah sama. Lantai 1 dikelola dengan sistem sewa lokal (ruang) senilai Rp. 500.000,- per bulan per lokal, sedangkan lantai 2 dikelola dengan model bagi hasil (revenue sharring atau omzet sharring) sebesar 7\% dari pendapatan harian para mitra pedagang. Namun, semua mitra pengusaha, baik di lantai 1 maupun 2, masih dikenakan biaya kebersihan, keamanan, dan listrik secara bulanan. ${ }^{40}$

Model bagi hasil yang dilakukan oleh PT. BAP semacam itu bukanlah model bagi hasil yang lazim dilakukan, karena bagi hasil biasanya dilakukan dengan model profit sharing (bagi untung) atau omzet sharing (bagi pendapatan) tanpa ada biaya-baiya tambahan lain di luar bagi hasil yang telah disepakati. Sementara model bagi hasil yang dilakukan di lantai 2 Pumanisa, selain model omzet sharing masih ada beban biaya tambahan sebagaimana disebutkan di atas. Akan tetapi karena sudah disepakati sejak awal, bisnis di lantai 2 Pumanisa berjalan dengan baik dan tanpa kendala yang berarti.

Model bisnis semacam itu memang bukanlah model bisnis yang sifatnya rigid, dalam arti kaku untuk diterapkan. Terbukti, kerjasama usaha di Pumanisa

\footnotetext{
${ }^{39}$ Wawancara dengan Joko Pitojo, Direktur Pengembangan PT. BAP, tanggal 20 Maret 2016.

40Wawancara dengan Sosi, Manajer Pumanisa PT. BAP, tanggal 25 Maret 2016.
} 
lantai 2 terus berjalan dan mengalami peningkatan dari tahun ke tahun. Hal itu karena PT. BAP tidak hanya memerankan diri sebagai pengelola yang hanya berhak mendapatkan omzet sharing $7 \%$ tiap bulannya, tetapi juga memberikan pembinaan secara berkala kepada semua mitra pedagang, baik berupa pengajian keislaman maupun pelatihan yang berhubungan dengan makanan halal dan pengelolaan usaha yang diridhai Allah.

Hanya sayangnya, model bisnis yang dilakukan di Pumanisa lantai 2 ini memiliki kelemahan dan rentan terjadi perselisihan. Kelemahan itu terletak pada sistem pelaporan pendapatan harian yang dilakukan oleh para mitra pedagang kepada PT. BAP. Selama ini besaran riel pendapatan harian yang dilaporkan tidak dapat dideteksi dengan baik. Hal itu karena PT. BAP belum menerapkan sistem pelaporan pendapatan satu kasir. Pelaporan pendapatan penjualan harian hanya mengandalkan kejujuran masing-masing mitra pedagang. Sehingga dapat saja ada mitra pedagang yang tidak jujur dalam pelaporannya. Tentu hal itu akan berimbas pada kurang maksimalnya pendapatan PT. BAP selaku pengelola Pumanisa.

\section{e. Depo Air Minum RO dan Isi Ulang “Quasa”}

Usaha Depo air minum isi ulang dan RO yang ditangani oleh PT. BAP dilaksanakan secara mandiri, tanpa bekerjasama dengan mitra kerja yang lain. Termasuk juga dalam hal kepemilikan modalnya yang secara penuh dimiliki oleh PT. BAP. PT. BAP memiliki karyawan yang secara khusus menangani usaha tersebut. PT. BAP hanya membeli pasokan air dari mitra pemasok air yang kemudian penanganan bisnisnya dilakukan oleh PT. BAP. Model ini adalah model yang umum dilakukan pada usaha depo air minum RO dan isi ulang yang masih berskala kecil. Sayangnya, merk Quasa hingga kini belum didaftarkan hak patennya oleh PT. BAP. Keberadaan merk ini akan berpengaruh pada segment pasar yang dibidik. Mengingat merk dagang Quasa belum terdaftar, maka air minum ini hanya bisa diedarkan untuk internal YBWSA. Karena pasarnya terbatas pada kalangan internal YBWSA, maka pengembangan usaha depo air minum isi ulang dan RO ini stagnan. ${ }^{41}$

41Wawancara dengan Fitriyanto. Manajer HRD PT. BAP, tanggal 20 Maret 2016. 


\section{f. Takessa (Tabung Kesehatan Sultan Agung)}

Takessa dikelola secara mandiri oleh PT. BAP. Tidak sebagaimana perusahaan asuransi lain yang melibatkan banyak nasabah, Takessa hanya melibatkan internal YBWSA. Artinya, anggota Takessa hanya terdiri atas karyawan YBWSA berikut bapel-bapelnya. Dengan pembayaran premi yang dipotongkan dari gaji karyawan sebesar 5\% dari gaji pokok (dalam realitasnya nilai uang tersebut tidak dipotongkan dari gaji karyawan tetapi ditanggung sepenuhnya oleh YBWSA), maka karyawan yang bersangkutan akan mendapatkan fasilitas jaminan kesehatan yang dikelola oleh Takessa. Premi yang dibayarkan oleh anggota ini dikelola PT. BAP untuk salah satunya membayar klaim-klaim dari anggota jika mengalami suatu hal pada dirinya (sakit/meninggal). Hal itu berarti, PT. BAP tidak memerlukan modal kerja, karena PT. BAP hanya mengelola aliran uang masuk (premi anggota) dan aliran uang keluar (klaim anggota). 42

\section{g. Minimarket Batama}

Minimarket Batama ini dikelola sendiri secara mandiri oleh PT. BAP dengan mengadopsi konsep minimarket pada umumnya. Maka sebagaimana minimarket lain, minimarket Batama tetap bekerjasama dengan mitra pemasok (suplier) untuk mensuplay pasokan barang-barang yang didisplay di minimarket. Hubungan kerjasama antara PT. BAP dan suplier sebatas hubungan akad dagang yang dibayar belakangan (konsinyasi). Jadi dalam pengelolaan minimarket batama, PT. BAP secara penuh menguasai modalnya.43

\section{h. Grosir Senkusa (Sentra Kulakan Sultan Agung)}

Model pengelolaan unit usaha grosir Senkusa tidak jauh berbeda dengan minimarket Batama. Hanya saja, Senkusa menjual produk dengan sistem grosir, bukan eceran sebagaimana yang dipraktikkan di minimarket Batama. ${ }^{44}$

\footnotetext{
42Wawancara dengan Fitriyanto, . Manajer HRD PT. BAP, tanggal 20 Maret 2016.

43Wawancara dengan Joko Pitojo, Direktur Pengembangan PT. BAP, tanggal 20 Maret 2016.

44 Wawancara dengan Joko Pitojo, Direktur Pengembangan PT. BAP, tanggal 20 Maret 2016.
} 


\section{h. Aset Manajemen}

Model pengelolaan bisnis di bidang asset manajemen ini, PT. BAP hanya mengelola persewaan lahan/bangunan yang dimiliki oleh YBWSA. Seluruh asset dimiliki YBWSA, sementara PT. BAP hanya bertindak sebagai pengelola persewaannya. Model ini tidak jauh berbeda dengan persewan lahan/ bangunan yang umum dilakukan. Hanya saja pada persewaan lahan parkir di Rumah Sakit Islam Sultan Agung, model pengelolaannya tidak hanya persewaan lahan, tetapi ada bagi hasil dari nilai profit yang diperoleh oleh mitra. Mitra ini mengelola parkir dengan membayar uang sewa lahan dengan nilai tertentu kepada PT. BAP dan di akhir bulan mitra ini diwajibkan untuk membayar bagi hasil $5 \%$ dari nilai profit yang diperolehnya selama 1 bulan yang terlaporkan. Dalam konteks ini PT. BAP memperoleh dua keuntungan, yaitu keuntungan dari menyewakan lahan parkir dan keuntungan bagi hasil dari nilai profit mitra selama 1 bulan yang terlaporkan. ${ }^{45}$

\section{i. Sultan Agung Tour (SAtour)}

Perusahaan Tour dan Travel yang berdiri pada tahun 2005 ini menangani berbagai jasa layanan pariwisata, antara lain: wisata domestik, ticketing (pesawat dan kereta), rental mobil, persewaan bus pariwisata, umrah dan haji. Ada beberapa produk yang ditangani oleh SAtour secara mandiri, tanpa melibatkan pihak lain, namun ada juga produk layanannya yang bermitra dengan pihak lain karena alasan tertentu.

Beberapa produk yang ditangani sendiri adalah wisata domestik, penjualan tiket pesawat dan kereta, rental mobil dan persewaan bus pariwisata. Untuk penjualan produk rental mobil dan persewaan bus pariwisata, SAtour sekedar mencari keuntungan dari jasa menjualkan armada milik pihak lain. Sementara penanganan produk yang bermitra dengan pihak lain adalah umrah dan haji. Dalam hal ini SAtour berkedudukan sebagai agen atau perwakilan dari perusahaan induk. SAtour tidak menangani secara keseluruhan program perjalanan umrah dan hajinya secara mandiri, tetapi berkonsorsium (bekerjasama) dengan pihak lain, mengingat perijinan umrah yang belum dimilikinya,

45 Wawancara dengan Bapak Joko Pitojo, Direktur Pengembangan PT. BAP, tanggal 20 Maret 2016. 
kemampuan modal yang kurang memadai dengan resiko kegagalan yang cukup tinggi, dan kondisidi lapangan yang seringkali berubah-ubah karena adanya kebijakan-kebijakan yang juga sering berubah-ubah (baik dari pemerintah Indonesia sendiri maupun dari pemerintah Arab Saudi).46

\section{j. PT. Radio Suara Kalimasadha Sakti (SA Radio)}

Perusahaan kedua di bawah payung LPU YBWSA adalah Radio Suara Kalimasadha Sakti (SA Radio), yaitu radio komersil yang selain menyuarakan dakwah Islam sesuai visi misi YBWSA, juga menjalankan usaha selayaknya bisnis di bidang kepenyiaran. Namun demikian, upaya perolehan pendapatan melalui bisnis media ini tidak terlalu ditekankan oleh YBWSA mengingat beberapa alasan, yaitu:

1) Dakwah Islam sangat diutamakan YBWSA. Maka dakwah melalui radio ini didorong agar terus berlangsung, dengan berbagai konsekuensinya.

2) Keberadaan SA Radio menjadi satu kebutuhan bagi YBWSA sebagai media untuk pendidikan umat menuju terwujudnya generasi khairu ummah.

3) Perlunya YBWSA memiliki media berbasis Islam sebagai penyeimbang media lain yang sering menginformasikan hal-hal yang berbau negatif terhadap umat Islam.

4) Radio ini juga menjadi media pembelajaran dan pelatihan bagi mahasiswa Unissula, terutama dalam hal kepenyiaran dan pengelolaan radio dakwah Islam. ${ }^{47}$

Mengingat beberapa alasan tersebut, maka bisnis LPU YBWSA melalui media radio ini lebih dilakukan dengan model pengelolaan mandiri, dibiayai sendiri tanpa ada kerjasama dengan pihak lain. Operasional dibiayai dominan oleh YBWSA, meskipun ada pasokan iklan dari luar YBWSA. Konsep ini yang menyebabkan usaha melalui SA Radio ini berjalan dengan baik, lancar dan tidak berkendala.

\footnotetext{
46 Wawancara dengan Reza Zaki Fahlufi, Manajer SA Tour, tanggal 22 Maret 2016. 2016.

47Wawancara dengan Roudhotul Badiah, Manajer Program dan Siaran SA Radio, tanggal 25 Maret
} 


\section{Relasi Pengelolaan Bisnis Syariah LPU YBWSA dengan Perkembangan Unit Usaha yang Dikelola}

Secara umum, model usaha yang diterapkan oleh sebuah perusahaan tergantung pada jenis usaha yang dikelola. Usaha yang dikembangkan LPU YBWSA yang dalam hal ini terwakili oleh PT. PT. BAP dan SA Radio, hubungan itu dapat tergambar pada hasil yang diperoleh. Usaha-usaha yang dikelola PT. BAP secara umum mengalami perkembangan yang cukup baik. Artinya ada peningkatan pendapatan dengan variasi model pengelolaan bisnis yang digunakan. Hal itu terlihat pada perkembangan bisnis SApress, SAtour, minimarket Batama, Pumanisa, Senkusa, air minum Quasa, dan property.

Sejak awal, SApress terus mengalami peningkatan pendapatan. Pada fase tertentu memang mengalami kerugian, tetapi kecenderungannya lebih pada peningkatan hingga tahun 2015 dengan omzet menembus angka kisaran 2 milyar/tahun. ${ }^{48}$ Model pengelolaan yang diterapkan PT. BAP melalui manajemen SApress sudah dianggap tepat dengan mengawinkan dua model, yaitu model pengelolaan mandiri dan model partnership, meskipun model partnership yang dilakukan bukan model partnership murni, tetapi lebih pada model partnership by case (kemitraan pada kasus-kasus tertentu).

Hal yang tidak jauh berbeda terjadi pada SAtour yang omzet terakhir pada tahun 2015 sudah menembus angka kisaran 4 Milyar. ${ }^{49}$ Sumbangan terbesar dari omzet itu diperoleh dari usaha umrah dan haji. Melalui program ini omzet SAtour terdongkrak cukup baik. Meskipun SAtour belum mengelolanya secara mandiri, tetapi usaha ini cukup potensial, karena terus meningkatnya animo masyarakat untuk beribadah ke tanah suci dan semakin lamanya masa tunggu untuk beribadah haji. Adapun model partnership yang diterapkan SAtour dalam pengelolaan program umrah dan haji ini dirasa sudah tepat mengingat kodisi SAtour yang belum memiliki perangkat yang memadai, selain perijinan penyelenggaraan ibadah umrah/haji yang belum dimiliki. Namun SAtour perlu berhati-hati dalam menetapkan mitra konsorsium (perusahaan umrah dan haji yang menjadi induk SAtour), karena jika salah mitra, hal itu akan berdampak

48Wawancara dengan Wahyu, Manajer Sultan Agung Press, pada tanggal 20 Maret 2016.

${ }^{49}$ Wawancara dengan Reza Zaki Fahlufi, Manajer SA Tour, tanggal 22 Maret 2016. 
pada keruntuhan bisnis SAtour mengingat bisnis ini adalah bisnis yang potensi kerugiannya sangat tinggi.

Sedangkan model usaha minimarket Batama dan Senkusa tidak jauh berbeda dengan model usaha minimarket konvensional. Mengingat posisi minimarket Batama dan Senkusa yang berada di dalam kampus, maka segment pasar kedua usaha tersebut juga terbatas pada komunitas kampus. Namun demikian, usaha ini mampu memperoleh omzet yang cukup baik, yaitu sudah kisaran 10 Milyar di tahun 2015.50

Kondisi beberapa unit usaha PT. BAP yang mengalami perkembangan sebagaimana tersebut di atas berbeda dengan kondisi Takessa yang akhirnya ditutup. Hal itu lebih disebabkan karena model pengelolaan yang tidak sesuai. Melalui pengelolaan mandiri dengan jumlah anggota yang terbatas (segmented), yaitu hanya karyawan YBWSA dan bapelnya, sangat mempengaruhi perolehan hasil usaha. Jumlah anggota Takessa yang terbatas dengan jumlah premi yang otomastis juga terbatas, tidak mampu menanggung beban klaim yang cukup besar. Inilah maka Takessa mengalami kerugian yang dari tahun ke tahun terus meningkat dan akhirnya terpaksa dihentikan operasionalnya. ${ }^{51}$

PT. BAP sebenarnya sudah berusaha mengatasi problem pengelolaan Takessa, dengan alternatif menaikkan premi asuransi atau menambah segment pasar. Namun dua hal itu juga mengandung problem yang tidak mudah untuk diatasi. Upaya menaikkan premi anggota akan mengalami penolakan yang cukup serius dari anggota, mengingat pemotongan yang cukup besar dari gaji akan berpengaruh pada menurunnya pendapatan mereka. Apabila biaya premi Takessa itu sepenuhnya ditanggung oleh YBWSA, maka akan terjadi beban yang cukup besar di YBWSA dengan resiko yang juga tetap besar (terutama resiko menanggung beban klaim yang tidak bisa diprediksi sebelumnya). Sementara upaya untuk meluaskan segment pasar anggota Takessa mempunyai problem pada nilai pertanggungan yang akan diberikan Takessa, apakah bisa bersaing dengan nilai pertanggungan yang diberikan oleh perusahaan asuransi lain yang selama ini sudah lebih dahulu berkembang, seperti Askes (sekarang BPJS)? Jika tidak mampu menyamai kualitas layanan yang diberikan

50Wawancara dengan Joko Pitojo, Direktur Pengembangan PT. BAP, tanggal 20 Maret 2016.

51Wawancara dengan Fitriyanto, SE., selaku Manajer HRD PT. BAP, tanggal 20 Maret 2016 
dengan nilai premi yang kompetitif, maka hal itu akan sia-sia saja ditawarkan kepada publik.

Pada usaha property yang dikelola dengan model partnership (kerjasama bagi hasil) dengan modal dari dua pihak, yaitu modal dari pemilik tanah dan modal usaha PT. BAP, ternyata cukup berhasil. Karena modal tanah dari pihak mitra, maka PT. BAP diringankan dalam modal awal. Hal inilah yang membuat PT. BAP mampu bertahan di usaha property ini. Secara riel ada peningkatan omzet yang cukup signifikan atas proyek dua perumahan yang dikelola oleh PT. BAP. Hal itu dibuktikan pada laporan akhir tahun 2011, dimana PT. BAP mengalami pertumbuhan asset yang signifikan sejak beroperasi di tahun 2009. Pada akhir tahun 2009, PT BAP mempunyai aktiva sebesar Rp. 777,5 juta. Pada akhir tahun 2010 meningkat menjadi Rp. 3,5 milyar.52 Pertumbuhan asset ini terutama dipengaruhi oleh berdirinya divisi property. Dari laporan Rugi Laba, PT BAP juga mengalami pertumbuhan pendapatan/omzet. Tahun 2009 omzet PT BAP sebesar Rp. 2,7 milyar, tahun 2010 meningkat menjadi Rp. 3,9 milyar, dan pada tahun 2011 menjadi Rp. 6 milyar. Pertumbuhan pendapatan 46,9\% pertahun dipacu karena bisnis property..$^{53}$

Sementara khusus untuk model bisnis yang dijalankan oleh SA Radio tidak jauh berbeda dengan model-model konvensional, karena usahanya dikelola dengan mengandalkan pemasukan dari perolehan iklan. Uang iklan itulah yang dipergunakan oleh manajemen SA Radio untuk memenuhi kebutuhan manajemen. Namun sebagian besar pendapatan justru diperoleh dari dropping YBWSA. Hal itu karena YBWSA sudah berkomitmen untuk membiayai SA Radio, mengingat keberadaan SA Radio sebagai media informasi, dakwah Islam dan media pendidikan rakyat sangat diperlukan oleh umat Islam.

\section{Kesimpulan}

Berdasarkan uraian sebagaimana tersebut di atas, maka model pengelolaan bisnis syari'ah di Lembaga Pengembangan Usaha (LPU) Yayasan Badan Wakaf Sultan Agung (YBWSA) Semarang dapat diambil kesimpulan sebagai berikut:

52Wawancara dengan Joko Pitojo, Direktur pengembangan PT. BAP, tanggal 20 Maret 2016.

53Wawancara dengan Joko Pitojo, Direktur pengembangan PT. BAP, tanggal 20 Maret 2016. 
Pertama, LPU menggunakan beberapa model bisnis, sesuai dengan tipe usaha yang dijalankan. Artinya, tipe dan jenis usaha yang dijalankan mempengaruhi model bisnis yang diterapkan. Tetapi ada satu konsep yang dijadikan dasar pijakan dalam berbisnis, yaitu LPU tidak melulu mencari keuntungan (profit oreinted), namun juga ada nilai manfaat (benefit oreinted). Beberapa fariasi model bisnis yang diterapkan oleh LPU, yaitu: 1) Sole proprietorship (kepemilikan tunggal), diterapkan pada unit usaha Takessa dan depo air minum Quasa (di bawah holding PT. BAP), dan SA Radio (berdiri sendiri di bawah LPU). 2) Partnership, diterapkan pada unit usaha property, retail, dan Pumanisa (ketiganya di bawah holding PT. BAP). 3) Kombinasi antara sole proprietorship dan partnership, yaitu: SApress, Asset Manajemen, dan SAtour (ketiganya di bawah holding PT. BAP)

Kedua, model pengelolaan bisnis yang diterapkan perusahaan dapat menentukan keberhasilan sebuah usaha/bisnis. Oleh karena itu menjadi sangat penting bagi perusahaan untuk memberikan perhatian pada model pengelolaan bisnis yang dijalankannya.

Guna mengembangkan model pengelolaan bisnis syari'ah, maka Lembaga Pengembangan Usaha (LPU) Yayasan Badan Wakaf Sultan Agung (YBWSA) Semarang perlu melakukan beberapa hal, yaitu: 1) LPU YBWSA perlu mengevaluasi beberapa model bisnis yang diterapkan sehingga tidak mengalami kerugian. Pengelolaan Takessa yang berujung pada kerugian menunjukkan kurang tepatnya analisa yang dilakukan dalam menentukan model pengelolaan bisnisnya. Juga pengelolaan Pumanisa sebaiknya diterapkan sistem pelaporan satu kasir agar lebih akurat dan maksimal profitabilitasnya. 2) Perlunya dilakukan dialog yang intensif sebagai edukasi kepada masyarakat maupun pelaku usaha mengenai model bisnis syari'ah yang belum banyak dikenal. Edukasi kepada masyarakat akan mampu menciptakan pasar syari'ah yang kuat karena masyarakat dapat mengetahui beragam model-model bisnis syari'ah, dan diarapkan akan lebih memilih model bisnis syaria daripada model bisnis konvensional. Edukasi terhadap pelaku usaha akan mendorong berkembangnya model-model bisnis syari'ah yang dikembangkan karena dapat memudahkan semua pihak dalam memilih usaha dengan model pengelolaan bisnis yang akan diterapkan.[w] 


\section{BIBLIOGRAFI}

Antonio, Muhammad Syafii, Muhammad saw-The Super Leader Super Manager. Jakarta: Prophetic Leadership and Management Centre, 2007.

Beekun, Rafiq Issa, Islamic Business Ethict, Virginia: International Institute of Islamic Thought, 1997.

Febianto, Irawan, Shariah Compliant Model of Business Entities, Bandung: Faculty of Economic University of Padjadjaran, 2010.

Ghazaly, Abdul Rahman, Fiqih Muamalah, Jakarta: Kencana Prenada Media Group, 2010.

Khan, Muhammad Akram, Types of Business Organisation in an Islamic Economy, An introduction to Islamic Economics \& Finance, CERT Publication SDN, BHD: Kuala Lumpur 2008.

Muhammad dan Lukman Fauroni, Visi al-Qur'an tentang Etika dan Bisnis, Jakarta: Salemba Diniyah, 2002.

Muslich, Etika Bisnis Islami; Landasan Filosofis, Normatif, dan Substansi Implementatif, Yogyakarta: Ekonisia Fakultas Ekonomin UII, 2004.

Naqvi,Syed Nawab Haider, Islam, Economics And Society, London and New York: Kegan Paul International, 1994.

Naqvi, Syed Nawab, Ethict and Economics: An Islamic Syntesis, telah diterjemahkan oleh Husin Anis: Etika dan Ilmu Ekonomi Suatu Sintesis Islami, Bandung: Mizan, 1993.

Osterwalder, A., Yves Pigneur, Alan Smith, and 470 practitioners from 45 countries, Business Model Generation, self published, 2009.

Profil PT. Radio Suara Kalimasadha Sakti Semarang, Semarang: SA Press, 2008.

Pusat Pengkajian dan Pengembangan Ekonomi Islam (P3EI) Universitas Islam Indonesia (UII) Yogyakarta, Ekonomi Islam, Jakarta: Raja Grafindo, 2013.

Setijawibawa, Melina, "Evaluasi Model Bisnis Pada Perusahaan X Menggunakan Business Model Canvas," Jurnal AGORA, Vol. 3 , No. 1, 2015.

Tim LPU YBWSA, Profil LPU YBWSA, Semarang: SA Press, 2003.

Tim BAP, Profile PT. BAP - LPU YBWSA Semarang, Semarang: SApress, 2010. 
Tim Redaksi Kamus Bahasa Indonesia, Kamus Bahasa Indonesia, Jakarta: Pusat Bahasa, 2008.

Umar, Husein, Businnes An introduction, Jakarta: Gramedia Pustaka Utama, 2000.

Wahjono, Sentot Imam, Bisnis Modern, Yogyakarta: Graha Ilmu, 2010.

Yusanto, Muhammad Ismail dan Muhammad Karebet Widjajakusuma, Menggagas Bisnis Islami, Jakarta: Gema Insani Press, 2002.

Zaroni, Akhmad Nur, "Bisnis dalam Perspektif Islam (Telaah Aspek Keagamaan dalam Kehidupan Ekonomi”, Mazahib, Vol. IV, No. 2, Desember 2007.

Wawancara dengan Drs. H. Tjuk Subchan Sulchan, Wakil Ketua Umum YBWSA sekaligus Ketua LPU YBWSA pada tanggal 4 Maret 2016.

Wawancara dengan Dr. H. Ahmad Didik Supadie, MM, Sekretaris Umum YBWSA pada tanggal 4 Maret 2016.

Wawancara dengan Heri Poerbantoro, SE. MM. Akt, selaku Direktur Utama PT. BAP, tanggal 20 Maret 2016.

Wawancara dengan Joko Pitojo, SE., selaku Direktur Pengembangan PT. BAP, tanggal 20 Maret 2016.

Wawancara dengan Sosi, SE., selaku Manajer Pumanisa PT. BAP, tanggal 25 Maret 2016.

Wawancara dengan Fitriyanto, SE., selaku Manajer HRD PT. BAP, tanggal 20 Maret 2016.

Wawancara dengan Roudhotul Badiah, S.Psi., selaku Manajer Program dan Siaran PT. SA Radio, tanggal 25 Maret 2016.

Wawancara dengan Wahyu, Manajer Sultan Agung Press, pada tanggal 20 Maret 2016.

Wawancara dengan Reza Zaki Fahlufi, selaku Manajer SA Tour, tanggal 22 Maret 2016. 


\title{
ANALISIS THE FIVE FORCES STRATEGY PADA AL-MUMTAZ PEDULI PONTIANAK
}

\author{
Ichsan Iqbal \\ Institut Agama Islam Negeri (IAIN) Pontianak \\ e-mail: ichsaniqbal26@yahoo.com
}

\begin{abstract}
This study discussed the implementation of the strategy management system on zakat management organizations 'Al-Mumtaz Peduli' Pontianak, West Kalimantan. Using the Five Forces Strategy analysis, the researcher will see to what extent Al-Mumtaz Peduli Pontianak is able to serve its function as a zakat agency competing with other organizations. This study was a field and qualitative research. The data had been obtained through interviews and documentation. This study concludes that Al-Mumtaz Peduli recognized other zakat institutions are partners that can work together to alleviate poverty and social problems. AlMumtaz gives services on orphans and wish every village has a religious preacher. Al-Mumtaz Peduli always do a socialization through seminars, mass and electronic media. Relating with collection and distribution of ZISWAF funds, AlMumtaz always improves its services to muzakki by giving activity and financial reports socialized by a per-three months' magazines.
\end{abstract}

Penelitian ini membahas implementasi sistem manajemen strategi pada organisasi pengelola zakat 'Al-Mumtaz Peduli' Pontianak, Kalimantan Barat. Dengan menggunakan analisa Five Forces Strategy, peneliti akan melihat sejauh mana Al-Mumtaz Peduli Pontianak mampu menjalankan fungsinya sebagai organisasi pengelola zakat ditengah persaingan dengan lembaga zakat yang lain. Penelitian ini merupakan penelitian lapangan dan kualitatif. Sedangkan data didapatkan melalui wawancara dan dokumentasi. Penelitian ini menyimpulkan bahwa Al-Mumtaz Peduli memandang organisasi pengelola zakat yang lain adalah mitra, supaya dapat bersinergi dalam mengentaskan kemiskinan social problem. Al-Mumtaz fokus segmen layanannya pada anak yatim dan berharap setiap desa ada memiliki satu dai. Al-Mumtaz Peduli harus selalu melakukan sosialisasi, baik melalui seminar, media massa dan elektronik. Dalam hal pengumpulan dan penyaluran dana ZISWAF dan Al-Mumtaz selalu meningkatkan pelayanan kepada muzakki berbentuk laporan kegiatan dan keuangan berbentuk majalah yang disampaikan per tri wulan.

Keywords: $\quad$ zakat; Al-Mumtaz Peduli; Five Forces Strategy; zakat agencies 